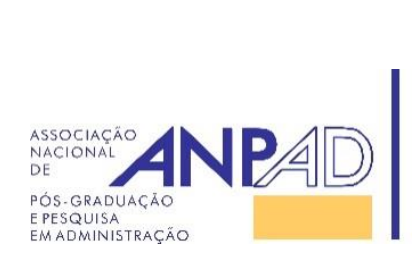

Disponível em

http://rac.anpad.org.br

RAC, Rio de Janeiro, v. 22, n. 5, art. 1,

pp. 639-660, setembro/outubro, 2018

http://doi.org/10.1590/1982-7849rac2018180135

\title{
Dynamic Capabilities and Ambidexterity: How are These Concepts Related?
}

\author{
Capacidades Dinâmicas e Ambidestria: Como estes Conceitos se Relacionam?
}

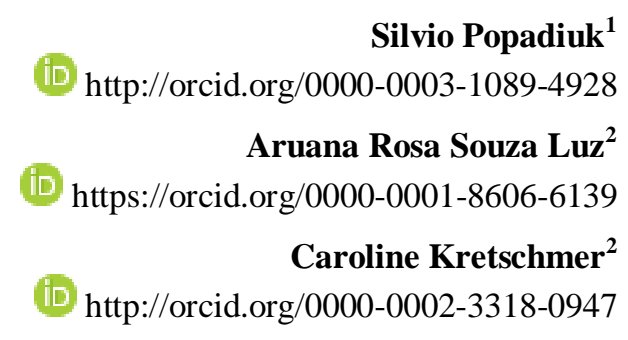

Universidade Presbiteriana Mackenzie, Centro de Ciências Sociais e Aplicadas, São Paulo, SP, Brasil ${ }^{1}$ Universidade do Vale do Rio dos Sinos, Escola de Gestão e Negócios, Programa de Pós-Graduação em Administração, São Leopoldo, RS, Brasil ${ }^{2}$

Artigo recebido em 25.05.2018. Última versão recebida em 21.08.2018. Aprovado em 21.08.2018. 


\title{
Resumo
}

As literaturas de ambidestria e capacidades dinâmicas contribuíram para discussões de gestão estratégica que buscam explicar como empresas alcançam e sustentam vantagens competitivas. Porém, poucos trabalhos dedicaram-se a entender como essas literaturas se inter-relacionam no nível de microfundamentos de sensing, seizing e reconfiguring de Teece (2007). A fim de preencher essa lacuna, investigamos trabalhos anteriores sobre teorias de estratégia e organizações que discutem a relação ambidestria-capacidades dinâmicas mediante uma revisão sistemática da literatura complementada por uma técnica de bola de neve (também propomos um modelo conceitual). A revisão da literatura que integra as duas abordagens mostra que os autores geralmente entendem a ambidestria como uma capacidade dinâmica. Além disso, nosso modelo revela elementos convergentes entre as duas literaturas como aprendizado; fontes de informação; design organizacional; gestão de recursos escassos, aumento de recursos através de terceirização e alianças; o papel da alta gerência e a participação das equipes nas decisões; por fim, a relevância da especialização de ativos e a governança organizacional. Com este artigo, pretendemos contribuir para a literatura ao sintetizar os trabalhos anteriores que relacionaram ambidestria e capacidades dinâmicas, propor um modelo conceitual baseado nos microfundamentos e identificar avenidas para pesquisas futuras.

Palavras-chave: capacidades dinâmicas; ambidestria; exploração; explotação; microfundamentos.

\begin{abstract}
The ambidexterity and dynamic capabilities (DCs) literature have contributed to strategic management discussions that seek to explain how firms achieve and sustain competitive advantages. However, few papers are devoted to understanding how they interrelate at Teece's (2007) micro-foundations of sensing, seizing, and reconfiguring capabilities level. To fill these gaps, we investigate previous works on strategy and organization theories which discuss the ambidexterity-DCs relationship through a systematic literature review complemented by using a snowball technique and then propose a conceptual framework. Review of the literature that integrates the two approaches shows that authors usually understand ambidexterity as a DC. Also, our framework reveals convergent elements between the two kinds of literature, such as learning; sources of information; organizational design; management of scarce resources; increase of resources through outsourcing and alliances; the role of top managers and teams' participation in decisions; and the relevance of asset specialization and organizational governance. This article aims to contribute to the literature by synthesizing early work relating ambidexterity and DCs; proposing a conceptual framework based on DCs' micro-foundations; and identifying avenues for future research.
\end{abstract}

Keywords: dynamic capabilities; ambidexterity; exploration; exploitation; micro-foundations.

JEL codes: D4, F61, O12. 


\section{Introduction}

Two theoretical perspectives - ambidexterity and DCs - have contributed to the strategic management discussion that seeks to explain how firms achieve and sustain competitive advantages. In organizational terms, ambidexterity is the organizational capability of managing contradictions and multiple tensions in dealing with exploration - the firm's search for experimentations, new alternatives, variability, flexibility, discovery, and innovation - and exploitation - the firm's refinement, use or optimization of existing resources, processes, competencies, knowledge, paradigms and technologies to obtain efficiency and effectuate implementation (March, 1991). DCs can be considered the consequence of distinct firm processes, configured by specific asset positions and path dependency (Teece, Pisano, \& Shuen, 1997), which are the essential constraints on an organization's ability to be ambidextrous.

The relationship between DCs and ambidexterity has not yet been sufficiently examined in the literature (Jurksiene \& Pundziene, 2016). Previous work has related ambidexterity and DCs, focusing on the macro relationship between them. More recently, authors have sought to fit ambidexterity literature strands into the three DC pillars (sense, seizing and reconfiguring) proposed by Teece (2007) (Birkinshaw, Zimmermann, \& Raisch, 2016, Zimmermann \& Birkinshaw, 2015). However, previous studies have not detailed the interrelationship between the ambidextrous literature specific elements and DCs' micro- foundations.

The common understanding of the DC construct and their micro-foundations remains open and in debate among researchers (Dixon, Meyer, \& Day, 2014; Peteraf, Di Stefano, \& Verona, 2013). The DC perspective covers different levels of analysis, ranging from management, decision-making processes, and organizational routines to environmental changes and competitive interactions (Helfat \& Peteraf, 2009). For being a broad and complex domain, there are several perspectives and varieties regarding its interpretations, which lead to multiple definitions of its elements. (Peteraf et al., 2013; Pisano, 2017). Thus, the understanding of its micro-foundations is broad and approached in different ways among researchers.

Micro-foundations refer to processes, individuals, structures, and interactions that influence capabilities development and execution (Felin, Foss, Heimeriks, \& Madsen, 2012). Understanding these micro-foundations requires multiple levels of analysis (Strauss, Lepoutre, \& Wood, 2017). For the analysis of this study, we used the approach proposed by Teece (2007), which presents DC microfoundations in a comprehensive and deep way. These micro- foundations are represented through organizational and managerial processes, systems, and structures. These elements build the sense, seizing and reconfiguring DC pillars. Therefore, Teece's (2007) approach provides a complete mapping, which allows us to analyze the relationships between DCs and ambidexterity proposed in this study.

The DC micro-foundations proposed by Teece (2007) are the distinct skills, processes, procedures, organizational structures, decision rules, and disciplines that undergird enterprise-level sensing, seizing, and reconfiguring capabilities. For this study, we seek ${ }^{1}$ to understand how the elements from ambidexterity literature are related to each one of these micro-foundations. In this paper, we call them micro-foundations of ambidextrous capability.

After discussing the early literature streams on ambidexterity and DCs, we propose a conceptual integration of these two theoretical perspectives based on Teece's (2007) tripartite framework of sensing, seizing, and reconfiguring pillars. Finally, we discuss this integration framework and bring to this study some theoretical contributions and proposals for future research.

\section{Theoretical Reference}

In this section, we present in a nutshell the DC and ambidexterity literature streams: terminology 
conceptualizations, mainstream theoretical research, and authors, and how these construct studies have evolved.

\section{Dynamic capabilities}

According to Teece, Pisano, and Shuen (1997), studies in DC perspectives started to be articulated based on the Resource-Based View (RBV) theory's conceptual framework and were accompanied by authors' approaches which contributed to organizational learning, innovation management, product and process development, intellectual property, and human resources (Nelson \& Winter, 1982; Penrose, 1959; Schumpeter, 1942; Teece, 1976, 1986, 1988). Aggregation of components and thoughts from diverse areas allow a broad research scope for understanding a company's resource management and attainment of sustainable competitive advantages (Teece, 2016).

The domain of investigation in DCs is a promising and active field of study, characterized by a multiplicity of interpretations, conceptualizations, and some disparities in the understanding of elements which constitute the terminology (Di Stefano, Peteraf, \& Verona, 2010). Although conceptualizations elucidate different attributes of capabilities, researchers agree that DCs are organizational processes built and incorporated into a company which allows changes in a company's resource base (Helfat et al., 2007).

DC studies by several researchers usually focus on different theoretical currents. Teece et al. (1997), consider DCs as "the firm's ability to integrate, build and reconfigure internal and external competencies to address rapidly changing environments." (p. 516). Eisenhardt and Martin (2000) assume that DCs consist of integration processes, reconfiguration, gaining resources, and release, aiming to combine them and create changes in the market. Zollo and Winter (2002) developed a DC conceptualization focused on organizational learning. Their definition covers learning elements, namely, as absorptive capacity. In line with these authors, Wang and Ahmed (2007) identified three main absorption capacity components - the adaptive, absorptive, and innovative capacity elements. Helfat and Peteraf (2003) presented the capacity life cycle (CLC) conceptualization, which focuses on capacity evolution stages of foundation, development, and maturity. Also, Winter (2003) postulates DCs as one of the tools that support strategic organizational analysis, which can be configured as a solution to a particular problem or produced internally.

These capabilities are high-level routines that enable decision-making and organizational change to generate superior results (Teece, 2007; Winter, 2003). Zahra, Sapienza, and Davidsson (2006) believe that the manager's role and the company's entrepreneurial team are important during the sensing opportunities phase because they modify existing routines and configurations and make appropriate decisions regarding necessary changes. Managers can promote major changes in the organization through decisions and investment options, as they can define the technological, market and product trajectories of a company (Teece, 2007). When making an in-depth analysis of the nature of the various DC classes, Teece's 2007 paper presented DC micro-foundations terminology. The author verifies the differences between managerial and organizational processes, procedures, systems, and structures that support each capability or capability class. In this way, DCs are broken down as follows: "(1) to sense and shape opportunities and threats; (2) to seize opportunities; and (3) to maintain competitiveness through enhancing, combining, protecting, and when necessary, reconfiguring the business enterprise's intangible and tangible assets"(Teece, 2007, p. 1319).

According to Teece (2007), the detection of opportunities and threats, as well as activities developed by companies, should be approached with learning, exploration, research, probing of technological possibilities, customer needs, and structural evolution of markets and competitors. Also, this phase contemplates how competitors, customers, and suppliers will respond to the changes, as well as the restrictions and rules imposed by regulatory mechanisms. Regarding seizing opportunities, it is understood that when there is a perception of opportunities and threats, it is necessary to approach them with new processes, products, and development of services. Improvements in activities, technological skills maintenance, and creation of strategies related to investment decisions are crucial for the 
development of a successful business model. Finally, threat management and reconfiguration of organizational structures are extremely relevant to a company's evolution, as well as to alignment with technological and market changes. It is necessary for the company to evaluate its activities and reformulate routines, realign activities, and adapt its business units. Besides, it is important to have a clear understanding of the organization's history, culture, and distinctive routines (Al-Aali \& Teece, 2014).

Managers can bring about major changes in the organization through their investment decisions and options, as they can define the technological, market, and product trajectories of the company (Teece, 2007). Top managers can evaluate and command changes in asset configurations (Teece, 2012). Thus, the main executive's strategic function lies in resource and asset allocation, combination and reconfiguration to address market changes, broaden the company's evolution and generate long-term value for investors (Teece, 2007).

Thus, the maintenance of the DCs requires entrepreneurial management, which is related to the discovery of new opportunities, as well as the recognition of problems and tendencies (Teece, 2007). This management involves the modification and improvement of routines and, mainly, the strategic actions to transform the company and model the ecosystem (Teece, 2012). Support of DCs requires top managers entrepreneurial, leadership skills on sense, seize, and reconfigure stages (Teece, 2012). Therefore, TMTs should bring together all three classes of DCs so that organizations can maintain and improve their evolutionary aptitude (Teece, 2007).

\section{Exploration, exploitation (E\&E) and ambidexterity}

Exploration is a firm's search for experimentations, new alternatives, variability, flexibility, discovery, and innovation (March, 1991). Relying solely on exploration can result in problems such as the inability to capture returns on innovation(O'Reilly \& Tushman, 2008; 2013). Exploitation is based on the refinement, use or optimization of existing resources, processes, competencies, knowledge, paradigms, and technologies to obtain efficiency and effectuate implementation. According to March (1991), organizations that engage in exploitation will be conditioned to a stable equilibrium, preventing them from dissociating themselves from the past and adapting to the contingencies that the environment imposes.

Ambidexterity is a terminology used to explain how firms work simultaneously with E\&E or not. Since Duncan (1976) first defined this term, many authors have described the ambidexterity construct as multifaceted, complex, and with a diversity of definitions and ways to be measured (Junni, Sarala, Taras, \& Tarba, 2013). Venkatraman, Lee, and Iyer (2007) understand ambidexterity as the organization's ability to manage contradictions and multiple tensions in dealing with the present and future, efficiency and effectiveness, alignment and adaptation, and optimization and innovation. Other authors consider ambidexterity as the organizational ability to simultaneously explore and exploit (Carter, 2015) or as a way of addressing the challenges that organizations face in simultaneously managing two competing goals (Birkinshaw \& Gupta, 2013). It can also be "a system that synchronously pursues the refinement and extension of existing competencies, technologies, and paradigms (i.e., exploitation) as well as experimentation with new alternatives and options (i.e., exploration)" (Carmeli \& Halevi, 2009, p. 211).

Ambidexterity studies are found in different areas (Nelson \& Winter, 1982; Raisch \& Birkinshaw, 2008; Tushman \& O'Reilly, 1996). There are three separate or exclusive literature streams that point to different ways firms can become ambidextrous: structural, contextual, and cyclical. The first streamstructural - emerged in 1996, with the seminal paper by Tushman and O'Reilly (1996). These authors define ambidexterity as "the ability to simultaneously pursue both incremental and discontinuous innovation and change results from hosting multiple contradictory structures, processes, and cultures within the same firm." (Tushman \& O'Reilly 1996, p. 24). They believe in structural separation as a way for firms to develop ambidexterity. Each (i.e., business unit, project team, employee) has different competencies, procedures, contexts, systems, incentives, processes, administrative rules, and cultures 
which allow them to execute only exploration or exploitation.

Some organizational antecedents are needed to achieve ambition in this case, such as the presence of a clear and convincing strategic intent and consensus among E\&E staff, the articulation of a common vision among the structural units, and the ability of senior leaders to manage contradictions (O'Reilly \& Tushman, 2008; Simsek, Heavey, Veiga, \& Souder, 2009; Talaulicar, Grundei, \& Werder, 2005). In some cases of organizations with separate structures, organizational disintegration can cross levels until reaching the managerial level (Lavie, Stettner, \& Tushman, 2010). It happens because management resources are limited, and because of managers' failure to achieve the precise balance. Thus, while members of the organization are cut off from conflicting demands, senior executives are expected to drive the organization into ambidexterity (Simsek, 2009).

Another perspective, contextual ambidexterity, alludes to organizational culture, context, and manager supporting individuals through environmental development and management; the invisible set of stimuli and pressures that motivate a company's professionals to develop their activities to achieve ambidexterity (Gibson \& Birkinshaw, 2004). For this to be possible, it is necessary to build processes and systems that encourage, support, and stimulate employees to adopt ambidextrous behavior whereby they make judgments about how best to divide their time between conflicting demands. This capability permeates all levels and organizational functions to achieve alignment and adaptability, emphasizing that the more the context is characterized by an interaction between discipline, elasticity, support and trust, the greater the ambidexterity level (Gibson \& Birkinshaw, 2004).

Studies in cyclical ambidexterity-also described as sequential alternation (Birkinshaw et al., 2016) - advocate that an organization alternate between periods of $E \& E$ and realign their structures and processes sequentially. In a model of perfect cyclical ambidexterity, the organization would go through periods of extreme exploration until it moved to exploitation and vice versa (Chen \& Katilla, 2008). The perfect alternation between exploration and exploitation allows the firm to adapt to environmental changes (Tushman, Virany, \& Romanelli, 1985) and create ambidextrous organizations in the long run (Siggelkow \& Levinthal, 2003).

Studies of this literature are usually longitudinal and suggest that sequential ambidexterity may be most useful in stable, slow-moving environments. Accordingly to O'Reilly and Tushman (2013), sequential ambidexterity may not be agile enough to keep pace with environmental changes, either because of the natural inertia of changing structure and routines or because environmental changes are faster than the change that the organization can implement.

Studies highlight some important factors of the organizational environment that impact ambidexterity, such as processes, structures, systems, cultures, and partnerships. For example, the search for ambidexterity requires organizations to manage internal tensions, associated with the $\mathrm{E} \& \mathrm{E}$ guidelines, as well as the demands arising from forces originating from the external environment, such as the economy, society, culture, and legislation (Popadiuk, 2015). Regarding the sectoral environment, factors such as competition, suppliers, dynamism, and customers are also associated with ambidexterity (Popadiuk, 2012).

Ambidexterity studies usually have perceptual performance measures (e.g., perceived performance compared to that of a competitor) and objective ones (e.g., company growth). In these studies, exploration contributed to performance through growth, while exploitation contributed to increasing profitability (Junni et al., 2013). Several studies report no effect of ambidexterity on performance, or an uncertain effect (Lin, Yang, \& Demirkan, 2007; Venkatraman, Lee, \& Iyer, 2007) and negative effects (Atuahene-Gima, 2005). Also, studies have found a positive correlation between ambidexterity and organizational performance (Gibson \& Birkinshaw, 2004; He \& Wong, 2004; Lubatkin, Simsek, Ling, \& Veiga, 2006). Ambidexterity positively relates to increased firm innovation, improved financial performance, higher survival rates, sales growth, market valuation and company survival (O'Reilly \& Tushman, 2013). The positive ambidexterity effects on performance are moderated by contextual factors (Chi, Zhao, Goerge, Li, \& Zhai, 2017; Junni et al., 2013), such as human affective and cognitive factors, and demographic and absorptive capability (Jansen, George, Van Den Bosch, \& 
Volberda, 2008; Popadiuk, 2015; Rothaermel \& Alexandre, 2009).

\section{Method}

We begin by examining how existing authors have related the literature of ambidexterity and DCs. We review papers published since O'Reilly and Tushman's (2008) early work up to 2017. We started our literature review searching for articles and reviews published between 1945 and 2017 on the Web of Science platform. The keywords used were dynamic capabil* and ambidext*. We refined the results by titles, abstract, and keywords. After that, we refined by the sub-areas of Business and Economic and looked into the categories of Management, Economics, and Business. Among the 144 results, just a few papers focused on understanding the interrelationship between ambidexterity and DCs.

After the literature review, we complemented our search by using the snowball technique. We search by relevant articles which were not inside the Web of Science platform. According to Greenhalgh and Peacock (2005, p. 1065): "Snowball methods such as pursuing references of references and electronic citation tracking are especially powerful for identifying high-quality sources in obscure locations." Table 1 shows our study found a total of 19 papers that deal with the relationship between the literature of ambidexterity and that of DCs.

Table 1

\section{Search Strategy and Study Selection Process}

\begin{tabular}{ll}
\hline Stage & Number of Articles \\
\hline Search according to parameters of Table 1 & 144 \\
Exclusion of articles from the bases after filter 1 applied & 24 \\
Exclusion of articles from the bases after filter 2 applied & 14 \\
Manual search for references of primary studies & 5 \\
Articles analyzed & 19 \\
\hline
\end{tabular}

Note. Source: Author elaboration.

After reading the selected papers, we individually analyzed them and compiled all main findings from each one inside an excel table. The researchers held meetings to analyze and discuss these findings. After that, we finished our analyses and presented them at a conference to a large group of researchers, incorporating proposed improvements to our findings.

Table 2 shows all papers analyzed, sorted by the source they were found. Almost ten years after the seminal work produced by O'Reilly and Tushman (2008), we still see these two authors at the top of the list, with three papers published on this theme. We also highlight Zimmermann and Birkinshaw, who published two papers. 
Table 2

List of Papers Analyzed

\begin{tabular}{ll}
\hline Literature Review & O'Reilly and Tushman (2008); Judge and Blocker (2008); Jansen, Tempelaar, Van Den \\
& Bosch, and Volberda (2009); O'Reilly, Harreld, and Tushman (2009); O'Reilly and \\
& Tushman (2011); Prange and Verdier (2011); Vogel and Guettel (2013); Zhan and Chen \\
& (2013); Pasamar, Cabrales, and Cabrales (2015); Carter (2015); Jurksiene and \\
& Pundziene (2016); Birkinshaw, Zimmermann, and Raisch (2016); Maijanen and Virta \\
& (2017)
\end{tabular}

Snowball Technique Nosella, Cantarello, and Filippini (2012); Kriz, Voola, and Yuksel (2014); García-Lillo,

Úbeda-García, and Marco-Lajara (2016); Zimmermann and Birkinshaw (2016); Guerra,

Tondolo, and Camargo (2016)

Note. Source: Author elaboration

The next section first presents the main works that try to understand the relationship between ambidexterity and DCs theories, highlighting the main points addressed by both literature streams in previous studies. After that, we present the framework integrating these two theoretical streams.

\section{Relationship between Dynamic Capabilities and Ambidexterity}

In this chapter, we first present how these literatures studies have been related since O'Reilly and Tushman (2008) first guided researchers toward a better understanding of ambidexterity as a DC. Next, we present DCs' micro- foundations, relating them to the ambidexterity literature stream, followed by the theoretical framework presentation.

\section{Early work relating ambidexterity to dynamic capabilities}

This section outlines previous works on strategy and organization theories which discuss the ambidexterity-DCs relationship. Although Venkatraman et al. (2007) studied ambidexterity as an organizational-level capability that affects organizational performance through critical organizational outputs, we understand that the first study on the ambidexterity-DCs relationship was addressed by O'Reilly and Tushman (2008). In this sense, some authors define ambidexterity as a DC in itself, which reconfigures resources (O'Reilly \& Tushman, 2008; Raisch \& Birkinshaw, 2008; Simsek, 2009). O'Reilly and Tushman (2008) argue that empirical findings in studies on the antecedents of ambidexterity reflect the same conditions under which DCs are most valuable (Eisenhardt \& Martin, 2000) and reinforce the importance of ambidexterity as a DC. The authors draw an analogy between DCs and ambidexterity when comparing Teece's tripartite taxonomy of sensing, seizing, and reconfiguring with the literature on ambidexterity's antecedents (O'Reilly \& Tushman, 2008).

As a DC, all three strands of organizational ambidexterity (structural, contextual, and cyclical) are a complex set of decisions and routines that help organizations sense and seize new opportunities through the reallocation of organizational assets and to mitigate the effects of path dependence (O'Reilly \& Tushman, 2008, 2013). Ambidexterity is not a source of competitive advantage but a facilitator of new resource configurations that can offer a competitive advantage to the firm. It does not mean random variations or tolerating inefficiency but a deliberate approach to variation-selection-retention that uses the firm's existing assets and capabilities and reconfigures them to address new opportunities (O'Reilly $\&$ Tushman, 2004; 2008).

The authors' subsequent works (O'Reilly, Harreld, \& Tushman, 2009; O'Reilly \& Tushman, 2011) also support this view, considering ambidexterity as a DC that incorporates a complex set of routines, including decentralization, differentiation, targeted integration, and senior leadership's ability to 
orchestrate complex trade-offs of E\&E. In this same sense, other studies also corroborate the understanding of ambidexterity as a DC: Judge and Blocker (2008) present the organizational capability for change as a DC that can enable the company to explore and exploit market opportunities. Jansen et al. (2009) consider ambidexterity as a DC at the organizational level. According to these authors, ambidextrous organizations mobilize, coordinate, and integrate dispersed, contradictory efforts; and allocate, combine, and recombine assets and resources in differentiated explorative and exploitative units.

In the context of international business, Prange and Verdier (2011) consider the ability to explore and exploit DCs as necessary for companies to achieve better performance in the internationalization process. Also, Zhan and Chen (2013) argue that these capabilities have an impact on international jointventure performance indicators.

Nosella et al. (2012), when performing a bibliographic investigation of DC literature, identified ambidexterity studies clustered inside them. These authors argued that almost all papers analyzed defined ambidexterity as an organizational capability that makes it possible to resolve different tensions that arise within an organization. Therefore, the authors conceptualized ambidexterity as a singular organizational capability.

On the other hand, García-Lillo et al. (2016) identified a cluster of DC studies inside ambidexterity literature's bibliometric analysis. These authors understand that ambidexterity is a DC (O'Reilly \& Tushman, 2008, 2013). They also comment that this perspective "arose during the last decade with the aim of improving the explanatory capacity of the resource-based view of the firm on the achievement of a sustainable competitive advantage by companies operating in highly changing environments" (García-Lillo, Úbeda-García, and Marco-Lajara, 2016, p. 11).

Vogel and Güttel (2013), when carrying out a bibliometric review of the literature of DCs, identify a cluster of literature on ambidexterity. According to the authors, this cluster reflects efforts within the research literature of DCs to discover the processes of evolution of the firm through the balance of exploratory and exploitatory learning processes. The analysis of the authors indicates that the ambidexterity cluster's E\&E capabilities are built on the same conceptual foundation as the integrative capabilities (Helfat \& Winter, 2011).

By quoting O'Reilly \& Tushman (2008) and Benner and Tushman (2003), Kriz et al. (2014), when studying ambidexterity in hypercompetitive markets, highlight ambidexterity as a type of DC. They argue that ambidexterity is a DC on the basis that "firms must reconfigure their competencies to maintain a balance between exploring new opportunities and exploiting the company's current routines to adapt to the demands of volatile environments." (Kriz et al., 2014, p. 289).

Pasamar et al. (2015) understand ambidexterity as an antecedent of sensing, seizing, and reconfiguring DCs. The authors propose that the sensing capacity will demand the exploration architecture of intellectual capital and the seizing capability will require structural ambidexterity (the dual architectures of E\&E), depending on environmental circumstances. Reconfiguration capability requires exploitation architecture. Similarly, for Maijanen and Virta (2017) ambidexterity is understood as the operationalization of capabilities and is contemplated within the scope of DCs. For these authors, E\&E are linked to the dimensions of sensing and seizing.

Carter (2015) understands ambidexterity in the same way as O'Reilly and Tushman (2008): as a DC necessary for managing conflict tensions. The paper deconstructs the organizational capability of ambidexterity into a typology of hierarchical dimensions that includes each type's enabling mechanisms and capabilities inside one organization. The premise of this paper is that ambidexterity can be meaningfully viewed as a set of hierarchical types of ambidexterity, each involving subsets of enabling mechanisms and capabilities. This typology distinguishes the state of ambidexterity, the process of adjusting and realigning the state, and the top management's logic for orchestrating shifts in the organizational context necessary to support varied states. This typology follows the same hierarchical framework for understanding distinctive organizational capabilities, that is, Winter's (2003) description of zero-, first- and second-order capabilities. 
Guerra et al. (2016) argue that one of the ways that an organization has to develop DCs is to become ambidextrous. They also define ambidexterity as a DC (O'Reilly \& Tushman, 2008) that enhances the company's adaptability to the changing environment, and therefore it is of paramount importance for long-term success. On the other hand, Heracleous, Papachroni, Andriopoulos, and Gotsi (2016) treat ambidexterity as an important DC in the innovation process. They argue that, in addition to being ambidextrous, a company needs to have other DCs that act as mediators in the process of promoting technological invention and commercialization.

Birkinshaw et al. (2016) argue that ambidexterity transpires through three different models of adaptation, which is how an organization deals with solving market dynamism problems and turbulences. Each model is a strand of ambidexterity theory (structural separation, contextual integration, named as behavioral integration, and cyclical alternation).

The nature of the DCs in each mode might also vary. To define what DCs are required for each model, Birkinshaw et al. (2016) separate Teece's three categories of DCs (sensing, seizing, and reconfiguring) and equate sensing with exploration and seizing with exploitation. Finally, reconfiguring is a higher-order capability that allows sensing and seizing to transpire, building the complementary reconfiguring capabilities to sustain the chosen adaptation. In other words, whereas Teece envisioned sensing, seizing, and reconfiguring as forming an (approximately) linear sequence of same-order capabilities, Birkinshaw et al. (2016) view sensing and seizing as lower-order capabilities and reconfiguring as a higher-order capability.

We understand Birkinshaw's model in two different ways. First, ambidexterity seems to be an antecedent of DCs. It means firms first choose the model of adaptation (for example, they determine that $\mathrm{E} \& \mathrm{E}$ activities will be developed in different structures, which means structural separation), and after that, they develop the lower- and higher-order capabilities.

A second way or analysis looks at ambidexterity as a manifestation of DCs (or as a consequence). First, firms manifest their capabilities through the process, such as new product development or acquisition processes (Eisenhardt \& Martin, 2000), and after that, this process defines the mode of adaptation that will be structured in the company.

Another important work from Zimmermann and Birkinshaw (2016) studies the interrelationship between the two theories. The authors emphasize the interdependence of the DC perspective, which explores the strategy (the role of strategy and business model choices in dealing with discontinuous change), and ambidexterity theory, which examines organizational contexts (arrangements that allow organizations to succeed in the short and long run through the reconciliation of E\&E). They understand that the two theories are antecedents of a firm's ability to succeed in the long term and complement each other.

Finally, Jurksiene and Pundziene (2016), relate the two approaches, suggesting that ambidexterity plays a mediating role in the relationship between DCs and organizational competitive advantage. Their theoretical analysis results show that ambidexterity represents a part of DCs, being configured as a "set of integrated processes of a DCs model" (Jurksiene \& Pundziene, 2016, p. 441).

This analysis proposed by Jurksiene and Pundziene aligns with the focus of our study and corroborates our idea of integrating the ambidexterity elements into the DC framework proposed by Teece (2007). Next, we present DCs' micro-foundations, emphasizing the elements we understand to be similar to the elements described in ambidexterity literature.

\section{Dynamic capabilities' micro-foundations and ambidexterity}

The evaluation of the main concepts of the two theories presents some convergences in the elements that constitute them. Both kinds of literature argue that some firms do learn and adapt to shifting environmental contexts. What drives the development of DCs and ambidexterity in organizations are constant and discontinuous environmental changes, requiring adequate strategic 
moves. First, an ambidextrous organization needs to have great adaptability and optimization capability that permeates the organization (Gibson \& Birkinshaw, 2004; Tushman \& O'Reilly, 1996). Similarly, the construction and orchestration of DCs require great flexibility and adaptability to address changes and the dynamism of the market and to continue to constantly evolve (Teece, 2007).

The two kinds of literature deals with complex and multifaceted phenomena. While DCs are based on the achievement of sustainable competitive advantage through the identification and use of opportunities coupled with the constant reconfiguration of tangible and intangible assets, the perspective of ambidexterity analyzes the company's orientation to the new, in addition to the improvement of existing resources, skills, knowledge, assets and technologies. Both approaches have mutual dependencies and interconnections with strategy and organizational structure (Zimmermann \& Birkinshaw, 2016). DCs focus more strongly on strategies and resources, while ambidexterity emphasizes organizational contexts and arrangements.

According to Jurksiene and Pundziene (2016, p. 8): "While DCs imply capabilities to absorb and adapt or modify, organizational ambidexterity ensures capabilities to learn, optimize, and balance." Both are essential for companies to remain in the market, grow and have good financial performance, culminating in the attainment and maintenance of competitive advantage (He \& Wong, 2004; Laaksonen \& Peltoniemi, 2016; Vogel \& Guttel, 2013).

To analyze the relationship between ambidexterity and DCs' micro- foundations, we separated the main themes of ambidexterity literature (management of the tension between E\&E, Top Manager Team (TMT) role, context, and organizational structure) into the three pillars of sensing, seizing, and reconfiguring.

\section{Sensing opportunities}

Sensing micro-foundations are connected to activities related to identification, exploration, and interpretation. These are contemplated in four groups: processes to direct internal R\&D and select new technologies; processes to tap supplier and complementary innovation; processes to tap developments in exogenous science and technology; and processes to identify target-market segments, changing customer needs, and customer innovation (Teece, 2007).

They are configured as processes to identify technological possibilities, customer needs, the evolution of industries and market structures, and the probing of competitors and suppliers' activities. The first group of micro-foundations relates to processes to select new technologies and direct internal $R \& D$. The discovery of opportunities and threats can be structured through internal R\&D activities, which are coordinated to map what is occurring in the business ecosystem. The second group includes the exploration of suppliers and complementary innovation. Supplier and complementary companies are assumed as important, given the fact that they propel innovations in the company's products. Similarly, the third group of sensing micro-foundations encompasses the company's processes to identify and utilize exogenous scientific and technological developments to have access to external innovations and new inventions. Lastly, the fourth group identifies changes in customers' needs, customers' innovations, and target-market segments (Teece, 2007).

Managers have practical, specific knowledge and understand customers' needs. These capabilities support managers when sensing new opportunities. Top managers are responsible for developing and testing hypotheses about market changes and technological landscapes, as well as synthesizing the meaning of this information for future organization decision making. Thus, TMT must develop conjunctures on working hypotheses and changes, going beyond problem-solving skills (Teece, 2007).

Regarding ambidexterity theory, a work rooted in evolutionary economics has started following a more precise approach based on the notion of search (Sidhu, Commandeur, \& Volberda, 2007). The operationalization of exploration is specifically about nonlocal information or knowledge-search behavior to discover fresh approaches to technologies, products, and businesses and to experiment with new alternatives (e.g., Rothaermel \& Alexandre, 2009; Sidhu et al., 2007). 
Since technology is considered the practical application of knowledge (Merriam-Webster, 2018), control over the variety of technological knowledge sought by firms is latent, especially in markets with a high degree of dynamism (Beckman, 2006; Bingham \& Eisenhardt, 2008; Coviello, 1994; Laursen \& Salter, 2006). In this sense, researchers of ambidexterity literature rooted in organizational learning also emphasize exploration as a search for new knowledge.

We understand that exploration occurs mainly inside the sensing micro-foundation. Both ambidexterity and DC research fields investigate the variety of information sources that can draw inspiration and guidance for an organization's innovative projects. Both refer to the search for new resources, assets, sources of knowledge, and innovation (O'Reilly \& Tushman, 2008; Teece, 2007).

The organizational context also plays a key role in the sensing phase. According to ambidexterity authors, ambidextrous companies can build a context that fosters the awareness of environmental opportunities and threats, as well as the perception of the need for exploration and exploitation.

The presence of leaders prepared to promote and manage transformations required by the internal and external environments is also an element addressed in both literature streams. Top management plays a significant role in the orchestration of DCs as they develop, validate, and reject scenarios to align their assets according to the needs (Teece, 2012). In contrast, the ambidexterity literature understands that the managers are an important organizational resource in the exploration phase once they know where and when to search for assets, resources, knowledge, and innovations, and they identify allies who support and help during the search. These ambidextrous managers are top-level senior executives with the ability to understand the company's different needs, articulate a clear and compelling vision, and demonstrate a commitment to ambidexterity (O'Reilly \& Tushman, 2004; Simsek et al., 2009; Talaulicar et al., 2005).

\section{Strategic decision skills/execution (Seizing)}

The seizing micro-foundations are based on product development, processes or services designed to seize previously identified opportunities. They involve choices related to marketing and investments to be made, thus requiring the creation or selection of business models. The four groups of microfoundations that constitute seizing are: the delineation of the customer solution and the business model; the selection of enterprise boundaries to manage complements and platforms control; the selection of the decision-making protocols; and the building of loyalty and commitment to avoid information asymmetry (Teece, 2007).

In short, seizing encompasses taking advantage of opportunities. All strategic decisions and execution soon after detection of technological and market opportunities proposed by this DC phase are also mentioned in ambidexterity literature that comes from the organizational design stream (O'Reilly \& Tushman, 1996). Duncan (1976), who first emerged with this literature, studied how organizations manage the stages of apprehension and implementation of innovation. The author understands these stages as necessary for an organization to accomplish evolutionary and revolutionary changes. We relate ambidexterity to seizing once the company's capability to organize itself and to integrate and allocate new resources, assets, knowledge, and innovation are discussed in the implementation stage proposed by Duncan (1976).

When dealing with the capability of E\&E, we understand that exploitation manifests inside the seizing phase because it is the company's capability to refine and improve products, knowledge, traditional markets. It is observed through the company's internal movements, resulting in economies of scale, efficiency in the orchestration of assets and resources, and others.

This phase consists mainly of the company's ability to manage conflicting demands and reduce the tension generated by the friction between E\&E. Ambidexterity studies argue over the organizational needs to balance scarce/ limited resources (Gupta, Smith, \& Shalley, 2006, March, 1991). Teece et al. (1997) present some concerns regarding the allocation of resources because the activities understood as seizing are often seen as competing or complementary to traditional ones. 
In the view of the ambidexterity literature stream, from the perspective of organizational design, companies increase their range of resources by putting activities of seizing outside organizational boundaries (for example, through outsourcing or alliances). Often the execution of the exploration activities occurs independently of exploitation activities (Gupta et al., 2006).

According to ambidexterity literature, such exploitative activities, when combined with exploration ones, need to be managed by the TMT. Managers' meetings serve as forums where the exchange of knowledge occurs in a free and open way; conflicts are solved, and shared perceptions are created. These manager's efforts can facilitate organizational ambidexterity. These teams, by their collaboration, make decisions together, and the exchange of information helps to overcome contradictions of information and conflicts associated with the tension between E\&E.

Thus, during the seizing phase, TMT has a key role. They connect the previous movements with the organization's goals and strategies. The manager acts as a pivot, engaging people and implementing changes required in the organization.

\section{Combination, reconfiguration, and asset protection skills (Reconfiguring)}

The reconfiguring micro-foundations capability comes right after detection and apprehension of opportunities. In this phase, the company addresses the management and orchestration of organizational assets and semi-continuous corporate renewal. The company needs to combine efforts to continually build, maintain, and adjust its business models, routines, structures, product offerings, and services. Reconfiguration refers to four groups: decentralization and near decomposability; core specialization; knowledge management; and governance (Teece, 2007).

In this context, the first micro foundation group is characterized by the firm's need to achieve decentralization and decomposition to achieve flexibility and responsiveness. The organizational units obtain an adequate level of autonomy but are still connected by activities coordinated by the firm. Organizational structure is important during the reconfiguring phase: the company's capability to organize itself to meet the improvements required by exploitation. Therefore, this micro foundation is equivalent to ambidexterity studies in the area of organizational design because it deals with the company's activities, centralization of activities, the degree of employee autonomy, manager dependence, and formalization of forms and tasks.

The second group deals with the management of asset specialization and strategies for the organizational structure. This management allows a company to continue systemic innovation and the continuous reach for strategic adjustment required for the business. The discussion of co-specialization also occurs in the ambidexterity literature. According to the structural studies strand, the specialized employee's profile usually shows either exploration or exploitation activities. All integration between $\mathrm{E} \& \mathrm{E}$ is discussed by managers at the TMT (Mom, 2006; Tushman \& O'Reilly, 1996). Also, ambidextrous researchers highlight another viable way to orchestrate resources based on contextual ambidexterity. This stream of research argues that a firm can be ambidextrous when employees and managers have a generalist profile that enables the performance of $\mathrm{E} \& \mathrm{E}$ activities at the same location (Gibson \& Birkinshaw, 2004).

The third group of micro-foundations includes learning, knowledge management, and corporate governance. Company processes that integrate and combine assets, mainly knowledge sharing and corporate governance structures, allow the creation of learning processes, an important asset to organizational reconfiguration.

Development of governance mechanisms, the last group, is a theme elucidated on in both kinds of literature. From the theoretical perspective of governance structure, management of exchange ratios aims at the sharing of mutual gains. Popadiuk (2015), bringing this concept to ambidexterity literature, argues that all these exchanges need to be coordinated and the better the governance process, the greater the chances of the organization focusing on ambidexterity. 
Inside these phases, the company's capability of preserving previously built context is important. But also important is the company's capability to constantly be attentive to new resources, assets, knowledge, all of which can require changes in its context.

During the reconfiguration, manager capability is important since they keep teams motivated to pursue agreed-upon actions through governance mechanisms (i.e., financial incentives). Governance involves team remuneration appropriate to encouraging technological transitions (Taylor \& Helfat, 2009). Thus, the importance of financial incentives for employees is addressed in both ambidexterity and DC literature.

From this mapping, we have constructed a matrix that briefly describes the relationship between the ambidexterity components and the DCs' micro-foundations (Table 3). Based on Teece (2007), we revealed elements of ambidexterity literature inside micro-foundations of DCs. To do so, we analyzed how ambidextrous components corresponds to each one of the DCs micro-foundations, evidencing whether these components permeate one or more micro- foundations. The result of this interaction translates into ambidextrous organizational and managerial capabilities.

Table 3

Relationship between Ambidexterity and Dynamic Capabilities

\begin{tabular}{lll}
\hline Ambidexterity & \multicolumn{1}{c}{ MICRO- FOUNDATIONS OF DYNAMIC CAPABILITIES } \\
\cline { 2 - 3 } Components & Sensing & Seizing \\
\hline Exploration & $\begin{array}{l}\text { The company's capability in } \\
\text { using local and nonlocal } \\
\end{array}$ & \\
& $\begin{array}{l}\text { resources, assets, sources of } \\
\text { knowledge, and innovation. }\end{array}$ \\
\hline
\end{tabular}

Exploitation

The company's capability to

constantly evolve. This is

observed through internal

movements of the company,

resulting in economies of

scale, efficiency in the

orchestration of assets and

resources, and others.

Organizational The company's capability to organize itself to integrate and Structure allocate new resources, assets, knowledge, and innovation.

\begin{tabular}{ll}
\hline Organizational & The company's capability to \\
Context & build a context that fosters \\
the awareness of & environmental opportunities \\
& and threats, as well as to \\
& perceive the need for \\
& exploration and exploitation.
\end{tabular}

Manager and Employee roles

The top management team's The capability of the capability to know where and manager to connect previous when to search for assets, resources, knowledge, and innovations, as well as to identify allies who support and help during this search.
The company's capability to The company's capability to absorb needed change. constantly be attentive to the changes in the context required by new resources, assets, knowledge acquisition, and improvements.

Manager capability to keep teams motivated to pursue agreed-upon actions. movements with the organization's goals and strategies. The manager acts as a pivot, engaging people and implementing changes required in the organization.

Note. Source: Author elaboration. 


\section{Conclusion}

This paper analyzed the relationship between micro-foundations of DCs and components of the ambidexterity concept. Review of the literature that integrates the two approaches has shown that the authors, for the most part, understand ambidexterity as a DC (Carter, 2015; García-Lillo et al., 2016; Guerra, Tondolo, \& Camargo, 2016; Kriz et al., 2014; Nosella, Cantarello, \& Filippini, 2012; O'Reilly \& Tushman, 2008). However, some studies perceive ambidexterity as being complementary to DCs, as a necessary element for the construction of these capabilities, or as a mediating element for organizational competitive advantage (Birkinshaw et al., 2016; Jurksiene \& Pundziene, 2016; Zimmermann \& Birkinshaw, 2016). There are also researchers who place ambidexterity as an element that precedes the construction of DCs and also as a consequence of the management of DCs (Birkinshaw et al., 2016; Pasamar, Cabrales, \& Cabrales, 2015).

We developed a conceptual framework based on Teece's (2007) micro-foundations of DCs (disaggregation of sensing, seizing, and reconfiguring capabilities). In our proposed conceptual framework, we revealed elements of ambidexterity literature inside DCs' micro-foundations. It allied with the theoretical underpinnings of the two approaches and articulated its elements. We identified ambidexterity literature elements (E\&E, organizational context, organizational structure, manager and employee roles) that permeate the sensing, seizing, and reconfiguring pillars of DCs. They underlie all DCs' micro-foundations.

Both ambidexterity and DC literature can be observed through routines inside organizations. Exploration capability can be observed through the sensing phase of searching for opportunities, knowledge, and innovation. The exploitation capability is observed in the seizing phase where the continuous realignment of resources is reflected in the processes to maintain efficiency and evolve.

Our study reveals elements of the ambidexterity literature that are addressed within the three dimensions of sensing, seizing and reconfiguring: organizational context, organizational structure, and management team. This shows that these are the only points widely discussed in the two theories. Structural organizational capability and context capability are configured as essential aspects for allowing organizations to sense opportunities, to promote the necessary movements for change, to take advantage of opportunities, and to enable the constant evolution, alignment, and realignment of assets and resources over time. Also, TMT plays a key role in the three DC dimensions to drive the actions and changes needed to ensure organizational evolution and competitiveness. The study contributes to the theoretical advancement in the concepts of organizational ambidexterity and DCs. We analyzed different author's views regarding the relationship between these literature and presented the convergent points between their fundamental elements. We advance DCs-ambidexterity relationship discussion when proposing a framework that associates main ambidexterity literature elements to each one of the DCs' micro-foundation pillars proposed by Teece (2007). Although previous articles have focused on the investigation of this relationship, the integration between the two kinds of literature has been carried out at a macro level. This article addresses the gaps pointed out in previous studies (Jurksiene \& Pundziene, 2016; Zimmermann \& Birkinshaw, 2016).

Thus, this analysis allows us to theoretically visualize the integration of these two areas of research that deal with several strategic and relevant organizational aspects. In this way, a multiplicity of possible future research emerges within this realm.

\section{Limitations and future studies}

The similarities and nuances in the views of the authors, coupled with the wide range of elements that make up the two perspectives, reflect the complexity of relating themes. Also, given the scarcity of papers that evaluate the relationship between ambidexterity and DCs, the first step of writing this article has been limited to the analysis of a small number of articles. 
Future studies may look at how enterprises operationalize micro-foundations of DCs through empirical research. How do firms from different market segments deal with sensing, seizing, and reconfiguring capabilities? How do micro-foundations evolve over time? Understanding how firms put these skills, processes, procedures, organizational structures, decision rules, and disciplines into practice may guide managers to better orchestrate a firm's resources and capabilities.

Other studies may seek to understand the relationship between DCs and long-term firm performance to deepen the understanding of how these capabilities can effectively sustain a competitive advantage. In-depth investigations should focus on how the management of these capabilities occur in practice and how together these approaches benefit strategic management.

Also, there are still no studies that investigate the functioning of DCs and their nature in practice, linking the managerial actions in this process (Teece, 2016). Research to be undertaken within this approach may also focus on a true understanding of how companies grow, become heterogeneous in their markets, and what are the sources of value creation and capture.

In analyzing the micro-foundations of DCs, we suggest a topic for future research: the agency problem, discussed in the micro-foundations of governance, that deal with the abuse of discretionary power and the use of corporate assets for private purposes. Since these problems become more severe as a business grows and the separation of ownership and management widens, researchers can advance studies of ambidextrous managers based on the perspective of agency theory. In which cases are ambidextrous companies more vulnerable to agency problems? What are the chances of this type of problem emerging within ambidextrous organizations? Do cases of abuse of discretionary power and the use of corporate assets for private purposes occur more often in companies that develop ambidexterity in a structural, contextual, or cyclical way? Will structural ambidextrous environments be more likely to develop a greater distance between ownership and management?

Given the scarcity of longitudinal studies in both ambidexterity and DC literature streams, we encourage future studies to evaluate whether an organization has undergone adaptations resulting from E\&E exchange. Also, since the interrelationship of DC and ambidexterity theories appears to be a promising area for future research, we encourage future researchers "to study these mutual dependencies and how they work in practice" (Zimmermann \& Birkinshaw, 2016, p. 17). What are the micro-foundations of DCs in firms that manifest E\&E about separated structures (Tushman \& O'Reilly, 1996)? Are these micro-foundations similar to the ones in firms that are ambidextrous in a contextual way (Gibson \& Birkinshaw, 2004)? Also, future studies can deepen empirical analyses relating to the ambidexterity and micro-foundation of DCs, as well as to how the various types of organizational ambidexterity can influence the development and orchestration of DCs and their relation to competitive advantage.

\title{
Note
}

\footnotetext{
${ }^{1}$ This study was financed in part by the Coordenação de Aperfeiçoamento de Pessoal de Nível Superior - Brasil (CAPES) Finance Code 001.
}

\section{Contributions}

\author{
1st author: Paper design - Initial approach - Preliminary draft - Guidelines for literature review - Adjustments of the structure \\ of the text - Final review. \\ 2nd author: Paper design - Preliminary draft - Development of literature review - Analysis results - Adjustments of the structure \\ of the text - Final review. \\ 3rd author: Paper design - Preliminary draft - Development of literature review - Analysis results - Final review.
}




\section{References}

Al-Aali, A., \& Teece, D. J. (2014). International entrepreneurship and the theory of the (long-lived) international firm: A capabilities perspective. Entrepreneurship Theory and Practice, 38(1), 95116. http://dx.doi.org/ 10.1111/etap. 12077

Atuahene-Gima, K. (2005). Resolving the capability-rigidity paradox in new product innovation. Journal of Marketing, 69(4), 61-83. http://dx.doi.org/10.1509/jmkg.2005.69.4.61

Beckman, C. M. (2006). The influence of founding team company affiliations on firm behavior. Academy of Management Journal, 49(4), 741-758. http://dx.doi.org/10.5465/amj.2006.22083030

Benner, M. J., \& Tushman, M. L. (2003). Exploitation, exploration, and process management: The productivity dilemma revisited. Academy of Management Review, 28(2), 238-256. http://dx.doi.org/10.5465/amr.2003.9416096

Bingham, C. B., \& Eisenhardt, K. M. (2008). Position, leverage, and opportunity: A typology of strategic logics linking resources with a competitive advantage. Managerial and Decision Economics, 29(2/3), 241-256. http://dx.doi.org/10.1002/mde.1386

Birkinshaw, J., \& Gupta, K. (2013). Clarifying the distinctive contribution of ambidexterity to the field of organization studies. Academy of Management Perspectives, 27(4), 287-298. http://dx.doi.org/10.5465/amp.2012.0167

Birkinshaw, J., Zimmermann, A., \& Raisch, S. (2016). How do firms adapt to discontinuous change? California Management Review, 58(4), 36-58. http://dx.doi.org/10.1525/cmr.2016.58.4.36

Carmeli, A., \& Halevi, M. Y. (2009). How top management team behavioral integration and behavioral complexity enable organizational ambidexterity: The moderating role of contextual $\begin{array}{llll}\text { ambidexterity. } & \text { Leadership 207-218. }\end{array}$ http://dx.doi.org/10.1016/j.leaqua.2009.01.011

Carter, W. R. (2015). Ambidexterity deconstructed: A hierarchy of capabilities perspective. Management Research Review, 38(8), 794-812. http://dx.doi.org/10.1108/MRR05-2014-0116

Chen, E. L., \& Katilla, R. (2008). Rival interpretations of balancing exploration and exploitation: Simultaneous or sequential? In S. Shane (Eds.), Handbook of technology and innovation management (Chap. 6, pp. 197-201). England: Wiley.

Chi, M., Zhao, J., Goerge, J. F., Li, Y., \& Zhai, S. (2017). The influence of inter-firm IT governance strategies on relational performance: The moderation effect of information technology ambidexterity. International Journal of Information Management, 37(2), 43-53. http://dx.doi.org/10.1016/j.ijinfomgt.2016.11.007

Coviello, N. E. (1994). Internationalizing the entrepreneurial high technology, knowledge-intensive firm (Ph.D. thesis). Department of Marketing, University of Auckland, New Zealand.

Di Stefano, G., Peteraf, M., \& Verona, G. (2010). DCs deconstructed: a bibliographic investigation into the origins, development, and future directions of the research domain. Industrial and Corporate Change, 19(4), 1187-1204. http://dx.doi.org/10.1093/icc/dtq027

Dixon, S., Meyer, K., \& Day, M. (2014). Building dynamic capabilities of adaptation and innovation: A study of micro-foundations in a transition economy. Long Range Planning, 47(4), 186-205. http://dx.doi.org/10.1016/j.lrp.2013.08.011

Duncan, R. B. (1976). The ambidextrous organization: Designing dual structures for innovation. In R. 
H. Kilmann, L. R. Pondy, \& D. P. Slevin (Eds.), The management of organization design (Vol. I, Chap. 9, pp. 167-188). Amsterdam: Elsevier

Eisenhardt, K. M., \& Martin, J. A. (2000). DCs: What are they. Strategic Management Journal, 21, $1105-1121$. http://dx.doi.org/10.1002/1097-0266(200010/11)21:10/11<1105::AIDSMJ133>3.0.CO;2-E

Felin, T., Foss, N. J., Heimeriks, K. H., \& Madsen, T. L. (2012). Micro-foundations of routines and capabilities: Individuals, processes, and structure. Journal of Management Studies, 49(8), 13511374. http://dx.doi.org/10.1111/j.1467-6486.2012.01052.x

García-Lillo, F., Úbeda-García, M., \& Marco-Lajara, B. (2016). Organizational ambidexterity: exploring the knowledge base. Scientometrics, 107(3), 1021-1040. http://dx.doi.org/10.1007/s11192-016-1897-2

Gibson, C. B., \& Birkinshaw, J. (2004). The antecedents, consequences, and mediating role of organizational ambidexterity. Academy of Management Journal,47(2), 209-226. http://dx.doi.org/10.5465/20159573

Greenhalgh, T., \& Peacock, R. (2005). Effectiveness and efficiency of search methods in systematic reviews of complex evidence: Audit of primary sources. BMJ, 33(7524), 1064-1065. http://dx.doi.org/10.1136/bmj.38636.593461.68

Guerra, R. de A., Tondolo, V. G., \& Camargo, M. E. (2016). O que (ainda) podemos aprender sobre capacidades dinâmicas. Revista Ibero-Americana de Estratégia, 15(1), 44-64. http://dx.doi.org/10.5585/riae.v15i1.2168

Gupta, A. K., Smith, K. G., \& Shalley, C. E. (2006). The interplay between exploration and exploitation. Academy of Management Journal, 49(4), 693-706. http://dx.doi.org/10.5465/amj.2006.22083026

He, Z.-L., \& Wong, P.-K. (2004). Exploration vs. exploitation: An empirical test of the ambidexterity hypothesis. Organization Science, 15(4), 481-494. http://dx.doi.org/10.1287/orsc.1040.0078

Helfat, C. E., \& Peteraf, M. A. (2003). The dynamic resource-based view: Capability lifecycles. Strategic Management Journal, 24(10), 997-1010. http://dx.doi.org/10.1002/smj.332

Helfat, C. E., Finkelstein, S., Mitchell, W., Peteraf, M., Singh, H., Teece, D., \& Winter, S. G. (2007). Dynamic capabilities: Understanding strategic change in organizations. Oxford: Blackwell Publishing

Helfat, C. E., \& Peteraf, M. A. (2009). Understanding dynamic capabilities: Progress along a developmental path. Strategic Organization, $7(1), \quad 91-102$. http://dx.doi.org/10.1177/1476127008100133

Helfat, C. E., \& Winter, S. G. (2011). Untangling dynamic and operational capabilities: Strategy for the (N) ever-changing world. Strategic Management Journal, 32(11), 1243-1250. http://dx.doi.org/10.1002/smj.955

Heracleous, L., Papachroni, A., Andriopoulos, C., \& Gotsi, M. (2017). Structural ambidexterity and competency traps: Insights from Xerox PARC. Technological Forecasting and Social Change, 117, 327-338. http://dx.doi.org/10.1016/j.techfore.2016.11.014

Jansen, J. J., George, G., Van Den Bosch, F. A. J., \& Volberda, H. W. (2008). Senior team attributes and organizational ambidexterity: The moderating role of transformational leadership. Journal of Management Studies, 45(5), 982-1007. http://dx.doi.org/10.1111/j.1467-6486.2008.00775.x

Jansen, J. J., Tempelaar, M. P., Van den Bosch, F. A., \& Volberda, H. W. (2009). Structural differentiation and ambidexterity: The mediating role of integration mechanisms. Organization 
Science, 20(4), 797-811. http://dx.doi.org/10.1287/orsc.1080.0415

Judge, W. Q., \& Blocker, C. P. (2008). Organizational capacity for change and strategic ambidexterity: Flying the plane while rewiring it. European Journal of Marketing, 42(9/10), 915-926. http://dx.doi.org/10.1108/03090560810891073

Junni, P., Sarala, R. M., Taras, V., \& Tarba, S. Y. (2013). Organizational ambidexterity and performance: A meta-analysis. The Academy of Management Perspectives, 27(4), 299-312. http://dx.doi.org/10.5465/amp.2012.0015

Jurksiene, L., \& Pundziene, A. (2016). The relationship between DCs and firm competitive advantage: The mediating role of organizational ambidexterity. European Business Review, 28(4), 431-448. http://dx.doi.org/10.1108/EBR-09-2015-0088

Kriz, A., Voola, R., \& Yuksel, U. (2014). The DC of ambidexterity in hyper-competition: Qualitative $\begin{array}{llll}\text { insights. Journal of } & \text { Strategic } & \text { Marketing, 22(4), } & \end{array}$ http://dx.doi.org/10.1080/0965254X.2013.876075

Laaksonen, O., \& Peltoniemi, M. (2016). The essence of dynamic capabilities and their measurement. International Journal of Management Reviews, 20(2), 184-205. http://dx.doi.org/10.1111/ijmr.12122

Laursen, K., \& Salter, A. (2006). Open for innovation: the role of openness in explaining innovation performance among UK manufacturing firms. Strategic Management Journal, 27(2), 131-150. http://dx.doi.org/10.1002/smj.507

Lavie, D., Stettner, U., \& Tushman, M. L. (2010). Exploration and exploitation within and across organizations. Academy of Management Annals, 4(1), 109-155. https://doi.org/10.1080/19416521003691287

Lin, Z., Yang, H., \& Demirkan, I. (2007). The performance consequences of ambidexterity in strategic alliance formations: Empirical investigation and computational theorizing. Management Science, 53(10), 1645-1658. http://dx.doi.org/10.1287/mnsc.1070.0712

Lubatkin, M. H., Simsek, Z., Ling, Y., \& Veiga, J. F. (2006). Ambidexterity and performance in smallto-medium-sized firms: The pivotal role of top management team behavioral integration. Journal of Management, 32(5), 646-672. 1 http://dx.doi.org/10.1177/0149206306290712

Maijanen, P., \& Virta, S. (2017). Managing exploration and exploitation in a media organization-A capability-based approach to ambidexterity. Journal of Media Business Studies, 14(2), 146-165. http://dx.doi.org/10.1080/16522354.2017.1290025

March, J. G. (1991). Exploration and exploitation in organizational learning. Organization science, 2(1), 71-87. http://dx.doi.org/10.1287/orsc.2.1.71

Merriam-Webster. (2018). Definition of technology. Retrieved January 22, 2018, from https://www.merriam-webster.com/dictionary/technology

Mom, T. J. M. (2006). Managers' exploration and exploitation activities: The influence of organizational factors and knowledge inflows (Doctoral dissertation). Erasmus University Rotterdam. Retrieved from https://repub.eur.nl/pub/7981

Retrievedfromhttp://hdl.handle.net/1765/7981

Nelson, R. R., \& Winter, S. G. (1982). An evolutionary theory of economic change. Cambridge, MA: Belknap Press of Harvard University Press.

Nosella, A., Cantarello, S., \& Filippini, R. (2012). The intellectual structure of organizational 
ambidexterity: A bibliographic investigation into the state of the art. Strategic Organization, 10(4), 450-465. http://dx.doi.org/10.1177/1476127012457979

O'Reilly, C. A., III, \& Tushman, M. L. (2004). The ambidextrous organization. Harvard Business Review, 82(4), 74.

O'Reilly, C. A., III, Harreld, J. B., \& Tushman, M. L. (2009). Organizational ambidexterity: IBM and emerging business opportunities. California Management Review, 51(4), 75-99. http://dx.doi.org/10.2307/41166506

O'Reilly, C. A., III, \& Tushman, M. L. (2008). Ambidexterity as a dynamic capability: Resolving the innovator's dilemma. Research in Organizational Behavior, 28, 185-206. http://dx.doi.org/10.1016/j.riob.2008.06.002

O'Reilly, C. A., III, \& Tushman, M. L. (2011). Organizational ambidexterity in action: How managers explore and exploit. California Management Review, 53(4), 5-22. http://dx.doi.org/10.1525/cmr.2011.53.4.5

O'Reilly, C. A., III, \& Tushman, M. L. (2013). Organizational ambidexterity: Past, present, and future. The Academy of Management Perspectives, 27(4), 324-338. http://dx.doi.org/10.5465/amp.2013.0025

Pasamar, S., Cabrales, A. L., \& Cabrales, R. V. (2015). Ambidexterity and intellectual capital architectures for developing dynamic capabilities: Towards a research agenda. European J. of International Management, 9(1), 74-87. http://dx.doi.org/10.1504/EJIM.2015.066672

Penrose, E. T. (1959). The theory of the growth of the firm. London: Basil Backwell.

Peteraf, M., Di Stefano, G., \& Verona, G. (2013). The elephant in the room of dynamic capabilities: Bringing two diverging conversations together. Strategic management journal, 34(12), 13891410. http://dx.doi.org/10.1002/smj.2078

Pisano, G. P. (2017). Toward a prescriptive theory of dynamic capabilities: Connecting strategic choice, learning, and competition. Industrial and Corporate Change, 26(5), 747-762. http://dx.doi.org/10.1093/icc/dtx026

Popadiuk, S. (2012). Scale for classifying organizations as explorers, exploiters or ambidextrous. International Journal of Information Management, $32(1), \quad 75-87$. http://dx.doi.org/10.1016/j.ijinfomgt.2011.07.001

Popadiuk, S. (2015). Exploração, explotação e ambidestria. São Paulo: Editora Mackenzie.

Prange, C., \& Verdier, S. (2011). Dynamic capabilities, internationalization processes, and $\begin{array}{llll}\text { performance. Journal of } \quad \text { World } & \text { Business, 46(1), }\end{array}$ http://dx.doi.org/10.1016/j.jwb.2010.05.024

Raisch, S., \& Birkinshaw, J. (2008). Organizational ambidexterity: Antecedents, outcomes, and moderators. Journal of Management, 34(3), 375-409. http://dx.doi.org/10.1177/0149206308316058

Rothaermel, F. T., \& Alexandre, M. T. (2009). Ambidexterity in technology sourcing: The moderating role of absorptive capacity. Organization Science, 20(4), 759-780. http://dx.doi.org/10.1287/orsc.1080.0404

Schumpeter, J. A. (1942). Socialism, capitalism, and democracy. New York: Harper \& Row.

Sidhu, J. S., Commandeur, H. R., \& Volberda, H. W. (2007). The multifaceted nature of exploration and exploitation: Value of supply, demand, and spatial search for innovation. Organization 
Science, 18(1), 20-38. http://dx.doi.org/10.1287/orsc.1060.0212

Siggelkow, N., \& Levinthal, D. A. (2003). Temporarily divide to conquer: Centralized, decentralized, and reintegrated organizational approaches to exploration and adaptation. Organization Science, 14(6), 650-669. http://dx.doi.org/10.1287/orsc.14.6.650.24840

Simsek, Z. (2009). Organizational ambidexterity: Towards a multilevel understanding. Journal of Management Studies, 46(4), 597-624. http://dx.doi.org/10.1111/j.1467-6486.2009.00828.x

Simsek, Z., Heavey, C., Veiga, J. F., \& Souder, D. (2009). A typology for aligning organizational ambidexterity's conceptualizations, antecedents, and outcomes. Journal of Management Studies, 46(5), 864-894. http://dx.doi.org/10.1111/j.1467-6486.2009.00841.x

Strauss, K., Lepoutre, J., \& Wood, G. (2017). Fifty shades of green: How micro-foundations of sustainability dynamic capabilities vary across organizational contexts. Journal of Organizational Behavior, 38(9), 1338-1355. http://dx.doi.org/10.1002/job.2186

Talaulicar, T., Grundei, J., \& Werder, A. V. (2005). Strategic decision making in start-ups: The effect of top management team organization and processes on speed and comprehensiveness. Journal of Business Venturing, 20(4), 519-541. http://dx.doi.org/10.1016/j.jbusvent.2004.02.001

Taylor, A., \& Helfat, C. E. (2009). Organizational linkages for surviving technological change: Complementary assets, middle management, and ambidexterity. Organization Science, 20(4), 718-739. http://dx.doi.org/10.1287/orsc.1090.0429

Teece, D. J. (1976). The multinational corporation and the resource cost of international technology transfer. Cambridge: Ballinger.

Teece, D. J. (1986). Profiting from technological innovation: Implications for integration, collaboration, licensing and public policy. Research Policy, 15(6), 285-305. http://dx.doi.org/10.1016/00487333(86)90027-2

Teece, D. J. (1988). Technological change and the nature of the firm. In G. Dosi, C. Freeman, R. Nelson, G. Silverberg, \& L. Soete (Eds.), Technical change and economic theory (pp. 256-281). New York: Pinter.

Teece, D. J. (2007). Explicating dynamic capabilities: The nature and micro-foundations of (sustainable) enterprise performance. Strategic Management Journal, 28(13), 1319-1350. http://dx.doi.org/10.1002/smj.640

Teece, D. J. (2012). Dynamic capabilities: Routines versus entrepreneurial action. Journal of Management Studies, 49(8), 1395-1401. http://dx.doi.org/10.1111/j.1467-6486.2012.01080.x

Teece, D. J. (2016). Dynamic capabilities and entrepreneurial management in large organizations: Toward a theory of the (entrepreneurial) firm. European Economic Review, 86, 202-216. http://dx.doi.org/10.1016/j.euroecorev.2015.11.006

Teece, D. J., Pisano, G., \& Schuen, A. (1997). Dynamic capabilities and strategic management. Strategic Management Journal, 18(7), 509-533. http://dx.doi.org/10.1002/(SICI)10970266(199708)18:7<509::AID-SMJ882>3.0.CO;2-Z

Tushman, M. L., \& O'Reilly, C. A. (1996). The ambidextrous organizations: Managing evolutionary and revolutionary change. California Management Review, 38(4), 8-30. http://dx.doi.org/10.2307/41165852

Tushman, M. L., Virany, B., \& Romanelli, E. (1985). Executive succession, strategic reorientations, and organization evolution: The minicomputer industry as a case in point. Technology in Society, 7(2/3), 297-313. http://dx.doi.org/10.1016/0160-791X(85)90031-4 
Venkatraman, N., Lee, C., \& Iyer, B. (2007). Strategic ambidexterity and sales growth: A longitudinal test in the software sector strategic. Unpublished Manuscript (earlier version presented at the Academy of Management Meetings, Honolulu, Hawaii, 2005). Retrieved from http://www.softwareecosystems.com/SMJManuscript_revised.pdf

Vogel, R., \& Güttel, W. H. (2013). The DC view in strategic management: A bibliometric review. International Journal of Management Reviews, 15(4), 426-446. http://dx.doi.org/10.1111/ijmr.12000

Wang, C. L., \& Ahmed, P. K. (2007). Dynamic capabilities: A review and research agenda. The International Journal of Management Reviews, 9(1), 31-51. http://dx.doi.org/10.1111/j.14682370.2007.00201.x

Winter, S. G. (2003). Understanding dynamic capabilities. Strategic Management Journal, 24(10), 991 995. http://dx.doi.org/10.1002/smj.318

Zahra, S. A., Sapienza, H. J., \& Davidsson, P. (2006). Entrepreneurship and dynamic capabilities: A review, model and research agenda. Journal of Management Studies, 43(4), 917-955. http://dx.doi.org/10.1111/j.1467-6486.2006.00616.x

Zhan, W., \& Chen, R. R. (2013). Dynamic capability and IJV performance: The effect of exploitation and exploration capabilities. Asia Pacific Journal of Management, 30(2), 601-632. http://dx.doi.org/10.1007/s10490-010-9235-3

Zimmermann, A., \& Birkinshaw, J. (2015). Reconciling capabilities and ambidexterity theories: A multi-level perspective. In D. J. Teece \& S. Heaton (Eds.), The Oxford handbook of dynamic capabilities (pp.1-24). Oxford: Oxford University Press. Retrieved from http://www.oxfordhandbooks.com/view/10.1093/oxfordhb/9780199678914.001.0001/oxfordhb9780199678914-e-008. http://dx.doi.org/10.1093/oxfordhb/9780199678914.013.008

Zollo, M., \& Winter, S. G. (2002). Deliberate learning and the evolution of dynamic capability. Organization Science, 13(3), 339-351. http://dx.doi.org/10.1287/orsc.13.3.339.2780

\title{
Author's Profiles
}

\author{
Silvio Popadiuk \\ Rua da Consolação, 896, 04068-040, São Paulo, SP, Brasil. \\ E-mail address: spopadiuk@gmail.com \\ Aruana Rosa Souza Luz \\ Av. Dr. Nilo Peçanha, 1600, 90470-280, Porto Alegre, RS, Brasil. \\ E-mail address: aruana.rosa@ hotmail.com, gregui.luz@hotmail.com \\ Caroline Kretschmer \\ Av. Dr. Nilo Peçanha, 1600, 90470-280, Porto Alegre, RS, Brasil. \\ E-mail address: carol.kretschmer@ brturbo.com.br
}

